\title{
Further Insights in the Etiology of Fear, Anxiety and Their Disorders in Children and Adolescents: The Partial Fulfillment of a Prophecy
}

\author{
Peter Muris
}

Published online: 23 January 2011

(C) The Author(s) 2011. This article is published with open access at Springerlink.com

\begin{abstract}
Although highly prevalent during childhood, symptoms of fear and anxiety are mostly short-lived and fairly mild. Initially, this led many child psychologists to the conclusion that fear and anxiety in children and adolescents should not be taken too seriously, and as a result these phenomena received relatively little research attention. During the past decade, this opinion has changed as researchers have increasingly demonstrated that a substantial minority of the youths do suffer from such high fear and anxiety levels that a diagnosis of an anxiety disorder is clearly warranted (e.g., Muris et al. 2000). In fact, epidemiological studies have shown that anxiety disorders are among the most prevalent forms of psychopathology among children and adolescents (Costello et al. 2003). Moreover, there is evidence indicating that a significant proportion of childhood anxiety disorders have a chronic course (Rapee et al. 2009).
\end{abstract}

The understanding that childhood fear and anxiety should be viewed as a clinically relevant phenomenon has led to a host of research on the pathogenesis of anxiety disorders in youths (Muris 2007). An analysis of the trends in publications on childhood anxiety disorders over the past 25 years (Muris and Broeren 2009) demonstrated that there has been a steady increase in research on the etiology of this type of psychopathology. In the discussion of their article, Muris and Broeren conclude that "even a greater amount of research can be expected in the near future" (p. 393). This special issue can be seen as the partial fulfillment of this prophecy. It includes eleven high-quality

P. Muris $(\bowtie)$

Institute of Psychology, Erasmus University Rotterdam, P.O. Box 1738, 3000 DR Rotterdam, The Netherlands

e-mail: muris@fsw.eur.nl papers of eminent research groups from all over the world (i.e., England, Japan, the Netherlands, and the United States), which cover a series of topics that are illustrative for what is currently happening in the front line of research in this area.

Table 1 provides a brief overview of various studies. As can be seen, the papers in this special issue can be grouped in three categories, each referring to a specific etiological factor. The first category is concerned with individual difference variables of vulnerability to fear and anxiety problems in youths, and contains papers focusing on neuroticism and repetitive negative thought (Broeren, Muris, Bouwmeester, \& Van der Heijden), behavioral inhibition and lack of attentional control (Sportel, Nauta, De Hullu, De Jong, \& Hartman), and behavioral inhibition to the unfamiliar (Muris, Van Brakel, Arntz, \& Schouten). The second category of papers pertains to family and parenting variables that are hypothesized to play a role in the origins and continuation of childhood anxiety disorders, such as anxious behavior of fathers (Bögels \& Perotti), father and mother involvement during cognitive-behavioral therapy (Podell \& Kendall), early learning experiences (Essau, Ishikawa, \& Sasagawa), and ethnic pride and parenting (Gray, Carter, \& Silverman). The third and final category of papers has to do with (the antecedents of) cognitive biases, which are generally thought to be involved in the maintenance of anxiety pathology in youths. This category includes studies on negative cognition in social anxiety (Miers, Blöte, \& Westenberg), automatic avoidance tendencies in spider fear (Klein, Becker, \& Rinck), maternal depression/panic symptoms and children's separation anxiety-related interpretation bias (Perez-Olivas, Stevenson, \& Hadwin), and parental threat cognitions and children's interpretation bias and anxiety (Creswell, Shildrick, $\&$ Field). 
Table 1 Overview of studies included in this special issue on childhood fear and anxiety

\begin{tabular}{|c|c|c|c|c|}
\hline Study & Etiological factor & Category & Fear/anxiety phenomenon & Sample \\
\hline 1. Broeren et al. & $\begin{array}{l}\text { Neuroticism and repetitive } \\
\text { negative thought }\end{array}$ & $\begin{array}{l}\text { Individual } \\
\text { differences }\end{array}$ & $\begin{array}{l}\text { Anxiety (depression, } \\
\text { sleep difficulties) }\end{array}$ & $\begin{array}{l}\text { Non-clinical, } N=158, \\
8-13 \text { years }\end{array}$ \\
\hline 2. Sportel et al. & $\begin{array}{l}\text { Behavioral inhibition and lack } \\
\text { of attentional control }\end{array}$ & $\begin{array}{l}\text { Individual } \\
\text { differences }\end{array}$ & Anxiety (depression) & $\begin{array}{l}\text { Non-clinical, } N=1806, \\
\text { young adolescents }\end{array}$ \\
\hline 3. Muris et al. & $\begin{array}{l}\text { Behavioral inhibition } \\
\text { to the unfamiliar }\end{array}$ & $\begin{array}{l}\text { Individual } \\
\text { differences }\end{array}$ & $\begin{array}{l}\text { Anxiety (other } \\
\text { psychopathology) }\end{array}$ & $\begin{array}{l}\text { Non-clinical, } N=261 \text {, } \\
5-8 \text { years }\end{array}$ \\
\hline 4. Bögels \& Perotti & Anxious behavior of fathers & Family & Social anxiety & None, review \\
\hline 5. Podell \& Kendall & $\begin{array}{l}\text { Father and mother involvement } \\
\text { during therapy }\end{array}$ & Family & Anxiety disorders & $\begin{array}{l}\text { Clinical, } N=45 \\
\text { 9-13 years }\end{array}$ \\
\hline 6. Essau et al. & Early learning experiences & Family & Anxiety & $\begin{array}{l}\text { Non-clinical, } N=299 \text {, } \\
12-17 \text { years }\end{array}$ \\
\hline 7. Gray et al. & Ethnic pride and parenting & Family & $\begin{array}{l}\text { Anxiety sensitivity, } \\
\text { anxiety }\end{array}$ & $\begin{array}{l}\text { Non-clinical, } N=266 \\
8-13 \text { years }\end{array}$ \\
\hline 8. Miers et al. & Negative social cognition & Cognitive bias & Social anxiety & None, review \\
\hline 9. Klein et al. & Automatic avoidance & Cognitive bias & Spider fear & $\begin{array}{l}\text { Non-clinical, } N=195 \text {, } \\
9-12 \text { years }\end{array}$ \\
\hline 10. Perez-Olivas et al. & $\begin{array}{l}\text { Maternal depression and panic } \\
\text { symptoms }\end{array}$ & Cognitive bias & $\begin{array}{l}\text { Interpretation bias, } \\
\text { anxiety }\end{array}$ & $\begin{array}{l}\text { Non-clinical, } N=60 \text {, } \\
\quad 7-14 \text { years }\end{array}$ \\
\hline 11. Creswell et al. & $\begin{array}{l}\text { Parental threat and distress } \\
\text { cognitions }\end{array}$ & Cognitive bias & $\begin{array}{l}\text { Interpretation bias, } \\
\text { anxiety }\end{array}$ & $\begin{array}{l}\text { Non-clinical, } N=110 \text {, } \\
5-9 \text { years }\end{array}$ \\
\hline
\end{tabular}

All these studies add further insights in the pathogenesis of anxiety problems in youths, and also provide new leads for future work in this intriguing domain of research. I thank the authors for submitting their outstanding contributions and their patience during the review process. Finally, I acknowledge the Editor-in-chief Nirbay Singh for offering me the opportunity to edit this special issue for the Journal of Child and Family Studies. As this issue nicely illustrates, both child and family factors should be considered when trying to understand the origins of anxiety pathology in youths, and as such I am pretty convinced that this series of papers will be of interest to the readership of the journal.

Open Access This article is distributed under the terms of the Creative Commons Attribution Noncommercial License which permits any noncommercial use, distribution, and reproduction in any medium, provided the original author(s) and source are credited.

\section{References}

Costello, E. J., Mustillo, S., Erkanli, A., Keeler, G., \& Angold, A. (2003). Prevalence and development of psychiatric disorders in childhood and adolescence. Archives of General Psychiatry, 60, 837-844.

Muris, P. (2007). Normal and abnormal fear and anxiety in children and adolescents. Oxford: Elsevier.

Muris, P., \& Broeren, S. (2009). Twenty-five years of research on childhood anxiety disorders: Publication trends between 1982 and 2006 and a selective review of the literature. Journal of Child and Family Studies, 18, 388-395.

Muris, P., Merckelbach, H., Mayer, B., \& Prins, E. (2000). How serious are common childhood fears? Behaviour Research and Therapy, 38, 217-228.

Rapee, R. M., Schniering, C. A., \& Hudson, J. L. (2009). Anxiety disorders during childhood and adolescence: Origins and treatment. Annual Review of Clinical Psychology, 5, 311-341. 